sciendo Порівняльна професійна педагогіка 9(1)/2019 Comparative Professional Pedagogy 9(1)/2019

DOI: $10.2478 /$ rpp-2019-0003

Postdoctoral Researcher of Pedagogy, Full Professor, NATALIYA MUKAN

Lviv Polytechnic National University

Address: Stepan Bandera St., 12, Lviv, Ukraine, 79013

E-mail: nataliya.v.mukan@lpnu.ua

$\mathrm{PhD}$ in Pedagogy, MARGARYTA NOSKOVA

Lviv Polytechnic National University

Address: Stepan Bandera St., 12, Lviv, Ukraine, 79013

E-mail: margaryta.v.noskova@lpnu.ua

Teacher, IRYNA ZINCHUK

Lviv Polytechnic National University

Address: Stepan Bandera St., 12, Lviv, Ukraine, 79013

E-mail: irynaz2009@i.ua

\title{
TEACHERS' DIGITAL COMPETENCE DEVELOPMENT: ESTONIAN STATE POLICY IN THE FIELD
}

\begin{abstract}
The article reveals the results of the content analysis of Estonian legislative and normative documents, which define the state educational policy regarding the development of both professional and digital competences of school teachers at the current stage of the education reforming of the country. The main objectives are defined as the theoretical analysis of scientific-pedagogical literature, which highlights different aspects of the problem under research; identification of the main features of Estonian legislative framework for professional development of public school teachers, especially in the field of digital competence formation. Teachers' professional development has been studied by foreign and Ukrainian scientists: L. Chance, A. Hollingsworth, N. Klokar, N. Mukan, V. Oliynyk, D. Ross, E. Villegas-Reimers etc. The paper, in particular, focuses on the provisions of the National Strategy for Continuing Education 2014-2020, the Professional Standards of the Teacher; The Law on Basic Schools and Secondary Schools, the State Program of Competent and Motivated Teachers and School Principals, which regulate goals, content and expected result of the development of the teacher's digital competence and its importance for the development of education and the state. The analytical references and results of the research of the Organization for Economic Development and Cooperation, dedicated to Estonian education, have been summarized. The research methodology comprises theoretical (logical, induction and deduction, comparison and compatibility, structural and systematic, analysis and synthesis), and applied (observations, questioning and interviewing) methods. The analysis has been carried out through the prism of expediency of borrowing the Estonian positive experience for the educational system of Ukraine, in particular, in the field of public school teachers professional development. The research results have been presented.

Keywords: state policy in the sphere of education, legislative and normative base, digital competence, professional standards, professional competence.
\end{abstract}


sciendo Порівняльна професійна педагогіка 9(1)/2019 Comparative Professional Pedagogy 9(1)/2019

\section{АНОТАЦІЯ}

У статті розкрито результати контент-аналізу законодавчих та нормативних документів Естонії, які визначають державну освітню політику щодо розвитку як професійних, так і цифрових компетентностей учителів загальноосвітніх шкіл на сучасному етапі реформування освіти країни. Визначено основні завдання щоодо теоретичного аналізу науково-педагогічної літератури, в якій висвітлюються різні аспекти досліджуваної проблеми; головні особливості законодавчої бази Естонії щуодо професійного розвитку вчителів загальноосвітніх шкіл, особливо у сфері формування цииррових компетентностей. Професійний розвиток викладачів вивчається іноземними та украӥнськими вченими: Л. Чанс, А. Холлінгсворт, Н. Клокар, Н. Мукан, В. Олійник, Д. Росс, Е. Віллегас-Реймерс тошо. Стаття, зокрема, зосереджується на положеннях Начіональної стратегї̈ неперервної освіти 2014-2020 рр., Професійних стандартів учителя, Закону про основні школи та середні школи, Державної програми компетентних $i$ мотивованих учителів $і$ директорів шкіл, які регулюють иілі, зміст $і$ визначають очікуваний результат розвитку цииррової компетентності вчителя $і$ його значення для розвитку освіти і держави. Узагальнено аналітичні дані та результати дослідження Організачії економічного розвитку та співробітничтва, присвяченого естонській освіті. Методологія дослідження охоплює теоретичні (логічний метод, індукцію та дедукцію, порівняльня та співставлення, структурно-системний метод, аналіз та синтез), а також практичні методи (спостереження, опитування та інтерв'ювання). Аналіз проведений крізь призму доиільності запозичення позитивного естонського досвіду для системи освіти Украӥни, зокрема, у сфері професійного розвитку учителів загальноосвітніх шкіл. Представлено результати дослідження.

Ключові слова: державна політика у сфері освіти, законодавча та нормативна база, ичирова компетентність, професійні стандарти, професійна компетентність.

\section{INTRODUCTION}

Small in size and population, only 1,3 million inhabitants, Estonia confidently takes the first positions among the EU countries in the field of digitalization of the country during the last decade. Moreover, Estonia was the first country in Europe where e-elections took place in 2005. In addition, with the help of an ID-card, which is simultaneously a passport and an identifier in electronic databases of the inhabitants of the country, citizens of Estonia can pay utility bills and taxes from any part of the world, get a certificate from government agencies, make a report, arrange a visit to a doctor, find out the results of a child's studying, book tickets to a concert or an airplane, etc. One can also apply for the e-citizenship of Estonia via the Single Window (see https://e-resident.gov.ee/). Information technologies have become an effective tool for Estonians to provide comfort, save time and, ultimately, have made it possible to substantially change and modernize both the life and mode of life of the country's average citizen.

There is a growing body of literature that recognises the importance of information technologies at the beginning of the twenty-first century. Nowadays, the active introduction of information technologies is a common trend in education. Estonian e-education is a longterm strategy of government which is intendent to realize its ambitious goal: "The educational digital revolution in Estonia aims to implement modern information technology more efficiently and effectively in learning and teaching, and to improve the digital skills of the entire nation. For example, it includes ensuring that every student receives the necessary 
sciendo Порівняльна професійна педагогіка 9(1)/2019 Comparative Professional Pedagogy 9(1)/2019

knowledge and skills to access modern digital infrastructure for future use (E-Estonia. Education, 2019).

For this reason, the teachers' level of digital competence and culture is extremely essential, since they are the primary link in a complex system of organization and ensuring the effective IT implementation in teaching and life of Estonians.

\section{THE AIM OF THE STUDY}

The authors decided to identify the connection between the state educational policy in the field of teachers' professional development, regarding their digital competence formation and development, and the teachers' own motivation to develop their digital skills and present the results of this study in the article.

\section{THEORETICAL FRAMEWORK AND RESEARCH METHODS}

Different theories exist in the scientififc literature regarding teachers' prpfessional development. A number of studies have examined teachers' professional development according to acmeological approach (Field, 2001; Joyce, 2010). A great deal of previous research into teachers' professional development has focused on axiological (Clarke, 1995, Kelley, 2010), andragogical (Beaty, 1998), intercultural (Gay \& Howard, 2000), competence (Cochran-Smith, 2003, Kauchak, 2010), constructivist (Andrew, 2010, Baker, 1999, Reeves, 2010), systemic (Pratt, 2000, Villegas-Reimers, 2003), structural and functional (Lieberman \& DarlingHammond, 2010, Scribner, 1999) approaches etc. Our research is based on the analysis of Estonian legislative and normative documents, analytical publications of the Organization for Economic Development and Cooperation (OECD) on the Estonian education and analysis of open access statistical data of Estonian teachers' professional development.

The research methodology comprises theoretical (logical, induction and deduction, comparison and compatibility, structural and systematic, analysis and synthesis), and applied (observations, questioning and interviewing) methods.

\section{RESULTS}

A draft of the Strategy for the Development of the Estonian Education System for 2012-2020 was published in 2011 (Estonia. Ministry of Education and Research. Estonian Cooperation Assembly, 2011). It identified 5 main challenges and trends in the development of education in Estonia: 1) the transition from learning of knowledge to learning through development and cooperation; 2) the teaching profession prestige increase; 3) the population level of education increase; 4) the ensurance of a stable relationship between the education system and the society needs for knowledge and the innovative economy; 5) the development of digital culture as a part of the Estonian cultural space.

Accordingly, after discussion and refinement, the Strategy for Continuing Education 2014-2020 was approved by the Government of Estonia and became a determinative document for the further reformation and development of educational institutions and pedagogical workers (Republic of Estonia. Ministry of Education and Research, 2014). "Continuing professional development is one of the most significant factors promoting the improvement of students' achievements. The necessity of teachers' continuing professional development, for them to be able to provide high-quality educational services and to improve the work of public schools, is emphasized" (Mukan, Myskiv \& Kravets, 2016, p. 20). To solve the problems, the "Basic Schools and Upper Secondary schools Act" (Basic Schools and Upper Secondary schools Act, 2010) was amended, the Regulations on qualification requirements for the principals, heads of the departments, teachers and support specialists were made (Direktori, õppealajuhataja, õpetajate ja tugispetsialistide kvalifikatsiooninõuded, 2013), State Program for Competent and Motivated Teachers and 
School Principals (Programm Pädevad ja motiveeritud õpetajad ning haridusasutuste juhid 2018-2021, 2017) was created. In order to increase the prestige of the teacher's profession at the state level, the Law on the minimum salary of the teacher, which in 2016 was 900 euro and the average salary of the teacher of Estonia in the same year was 1168 euro, was approved. In 2013 the teacher attestation system, which existed according to the model of the Soviet school, was revoked; new teacher standards on the basis of a competent approach were developed and approved instead.

"Computers and information technologies (IT) are being created and improved with the aim to help people think, act and learn effectively. They not only broaden the professional potentialities but also require mastering new types of knowledge and expertise in the process of continuing professional development" (Mukan, Noskova, \& Baibakova, 2017). Hence, the lifelong learning strategy 2014-2020 has identified digital competences of a citizen as a priority and defined their need to be continually updated; as a result educators and teachers, whose digital competence is becoming more significant, play an important role in ICT mastering: "The digital competence of schools, school leaders, teachers and students still needs to be increased. In addition, national e-assessments (eexams and e-level tests) are progressively developed and implemented. The use of digital learning materials, in general and vocational education, contributes to better teaching and learning and the development of students ICT skills. Schools' ICT infrastructure still needs to be improved" (European Schoolnet. Estonia. Country report on ICT in Education, 2015, p. 1). A comprehensive approach to the target goals and a clear plan for the implementation of the Strategy for the Development of the Estonian Education permits us to observe some positive results nowadays, indicating their further discussion more particularly, revealing their usefulness to the educational system of Ukraine, which is currently undergoing active reformation.

Therefore, five main challenges of Estonian education, the solution of which is significant at a current stage of educational system development, are closely connected to the state plans for social and economic growth of the country, decentralization and digitization of which have become the successful first stage of the development since the proclamation of independence.

The main feature of the Estonian school, which distinguishes it significantly from the Ukrainian one, is its autonomy and independence in solving the vast majority of issues related to the content and methods of teaching. The school principal has wide range of power and together with the teaching staff, the school board of trustees, local authorities (rural or urban), which the school belongs to, draws up and implements the program of educational institution development, as well as emphasizes its features and advantages in the process of future competent citizen of Estonia formation. The school significantly depends on the co-ordinated cooperation of the school itself, the local community and parents, which in its turn allows maintaining authenticity and, correspondingly, developing an educational institution in accordance with state requirements and standards, but taking into account local characteristics. The costs for the school and its employees support as well as development are directly related to the community's capabilities and demands, the state requirements for the level of students' training and teachers' professional level. It follows that the school is responsible for community educational needs assurance, based on the state standards of education.

Typically the proprietary is responsible for creating and maintaining the digital infrastructure of the school: "Such sufficient infrastructure includes hardware and software; including laptops and tablets for students and teachers, necessary network solutions and IT 
sciendo Порівняльна професійна педагогіка 9(1)/2019 Comparative Professional Pedagogy 9(1)/2019

systems, local and broadband connectivity as well as virtual learning environments. The government is responsible for the strategic planning, design of national curricula and setting up a framework for school curricula" (European Schoolnet. Estonia. Country report on ICT in Education, 2015), and he is certainly interested in its effective application and development. This requires highly qualified teachers who are able and wish to fill it and keep it in an active state.

The vast majority of Estonian schools, as well as Ukrainian ones, are rural and often underfilled. Despite this, each school is connected to a high-speed Internet and equipped with computers or laptops, projectors and other peripheral equipment, which teachers and students actively use in training. The application of students' and teachers' personal gadgets has also become remarkable. This is primarily due to the fact that Estonians are constantly using smartphones and computers to meet their personal needs. Moreover, in pre-school educational institutions children are taught the fundamentals of programming and logical thinking while playing, and the lessons on the fundamentals of safe Internet usage are also compulsory. Elementary school students are taught how to use a bank card, make electronic purchases, analyze the expediency of using certain Internet services and computer programs in simple household cases. Besides, the curriculum does not include "Informatics" as a separate subject, the digital competence and students' culture, as the key competence, are formed integratively. Digital technologies are regarded as an instrument that needs to be used effectively.

In addition, each school has an information technology engineer, responsible for encouraging teachers to use digital technologies, disseminating good practices, organizing teachers training and experiences sharing, monitoring and analyzing the results of information technologies implementation into the learning process in general and in teacher work in particular.

Thus, a comprehensive system of teachers professional development in the field of using information technologies in education that would correspond to the level of society development, its needs and at the same time would stimulate teachers to use IT in their professional activity, form the skills of searching new online services, applications and technologies for learning and collaboration in and out of the classroom, as well as using already familiar ones, is necessary.

This approach was put into the new mechanism for organizing and ensuring teachers professional development, introduced in 2013 instead of certification, which is very familiar to the present Ukrainian experience. Teachers' attestation offered the possibility to confirm the professional category or receive the higher one on the basis of objective indicators, years of employment and the certificate of advanced training in the corresponding courses. However, in the process of educational reform, decentralization, acquisition of school autonomy in choosing the methods for training, organization and the facilities for ensuring its quality etc, the system of teachers' attestation has become incongruous to the real state of affairs. Moreover, in some cases such approach has put brakes on innovation processes and devalued the teachers' initiative, which has been in total disregard.

Gradually, the formal approach in determining the professional categories of the teacher has been abandoned. This is reflected in the Occupational Qualification Standards that were updated in 2013 (Occupational Qualification Standards, 2013). Thus, the following principles are applied to the attribution of professional qualifications in Estonia, in particular: "competence based approach: bases for assessment of occupational qualification are real skills and knowledge, irrespective of the ways of learning; is voluntary, unless 
sciendo Порівняльна професійна педагогіка 9(1)/2019 Comparative Professional Pedagogy 9(1)/2019

otherwise prescribed by law; assessment is separated and independent from teaching; takes place on the basis of person's application; professional examination is for a fee" (Main principles of awarding occupational qualifications, 2013). The skills and competences which a teacher applies in practice, his professional portfolio, which is first and foremost valued for professional growth, have become essential for the professional development. This is documented in the State Program for Competent and Motivated Teachers and School Principals: 'Teachers' and headmasters' assessment and salaries are based on the job qualification requirements and their job performance. The digital competence of schools, school leaders and teachers varies. In order to ensure full support to the learners' development of digital competences, all schools and relevant personnel should be digitally competent" (European Schoolnet. Estonia. Country report on ICT in Education, 2015, p. 1).

It should be emphasized that the teacher's digital competence is not assessed at the state level, but taken into account while determining the teacher's qualifications. "Since 2013, the evaluation model for teachers' educational technology competences is integrated in the national teacher professional standard. Therefore, teachers have to evaluate and demonstrate their digital skills when they apply for occupational qualifications. Digital competences are part of the teachers' transversal competences mentioned in the professional standard" (European Schoolnet. Estonia. Country report on ICT in Education, 2015 , p. 5). Therefore, teachers are encouraged to receive certificates of international certification programs, namely European Computer Driving Licence - ECDL and European Pedagogical ICT License (European Computer Rights Licensing Certificate).

The results of this studty indicate, that it is significant for teacher to develop his/her professional competences, in particular the digital ones, as it is unknown which skills and knowledge he/she will need for work. Starting with the 90s of the twentieth century an Estonian teacher has the freedom to choose and use forms, methods, and techniques for academic process, determine the sequence of educational topics learning, has the right to independently choose textbooks and digital educational resources, develop educational content, formulate requests for necessary didactic and methodological materials, choose the courses for advanced training, etc. This independance gives him the possibility to selfassess the level of his/her digital competence. Meanwhile, the effectiveness of using a digital resource by a teacher is easily tracked in the digital environment of an educational institution.

\section{CONCLUSIONS}

The following conclusions can be drawn from the present study. The Estonian state policy for the development of a teacher's digital competence is based on a number of legislative and regulatory acts that regulate a new stage of educational system reforming and focus on the formation and integrated development of a teacher's professional competence. The gradual, open and consistent actions of the Government and the Ministry of Education and Science of Estonia in this sphere, as well as the results of changes implementation, are not sufficiently investigated in the national science, but are essential to Ukraine, since our educational system is currently undergoing active reformation. Finally, a particular attention should be paid to the thorough examination of the results of public policy implementation in this issue directly in Estonian schools.

\section{REFERENCES}

1. Basic Schools and Upper Secondary Schools Act. (2010). Retrieved from https://www.riigiteataja.ee/akt/115032014037\#para76lg3. 
2. Direktori, õppealajuhataja, õpetajate ja tugispetsialistide kvalifikatsiooninõuded. (2013). Retrieved from https://www.riigiteataja.ee/akt/130082013005. education/.

3. E-Estonia. Education. (2019). Retrieved from https://e-estonia.com/solutions/

4. European Schoolnet. Estonia. Country report on ICT in Education. (2015). Brussel. Retrieved from http://www.eun.org/documents/411753/828792/Country+Report+ Estonia+2015.pdf/c7822e64-16be-43f4-bd97-d0c296b4d7d3.

5. Main principles of awarding occupational qualifications. (2013). Tallin. Retrieved from https://www.kutsekoda.ee/en/main-principles-of-awarding-occupationalqualifications/.

6. Mukan, N., Myskiv, I., \& Kravets, S. (2016). The characteristics of the system of continuing pedagogical education in Great Britain, Canada and the USA. Comparative Professional Pedagogy, 6 (2), 20-25.

7. Mukan, N., Noskova, M., \& Baibakova, I. (2017). The formation of school principals' readiness to use internet technologies in their work in the system of continuous pedagogical education. Science and Education, 4, 123-132.

8. Occupational Qualification Standards. (2013). Tallinn. Retrieved from https://www.hm.ee/ en/activities/kvalifikatsioonid/occupational-qualifications.

9. Programm Pädevad ja motiveeritud õpetajad ning haridusasutuste juhid 20182021. (2017). Retrieved from https://www.hm.ee/et/tegevused/opetaja.

10. Republic of Estonia. Ministry of Education and Research. (2014). Estonian Lifelong Learning Strategy 2020. Tallinn. Retrieved from https://www.hm.ee/en/estonianlifelong-learning-strategy-2020

11. Republic of Estonia. Ministry of Education and Research. Estonian Cooperation Assembly. (2011). The Five Challenges of Estonian Education. Estonian Education Strategy 2012-2020. Tallinn. Retrieved from https://www.kogu.ee/public/H_strateegia_tegevused/ Haridusstrateegia_ENG_spreads_appendix.pdf. 